\title{
PENYAKIT MALARIA DAN MEKANISME KERJA OBAT-OBAT ANTIMALARIA
}

\author{
Roihatul Muti’ah \\ Jurusan Kimia, Fakultas Sains dan Teknologi, UIN Maulana Malik Ibrahim Malang \\ Corresponding_author: roihatulmutiah@gmail.com
}

\begin{abstract}
Malaria is one of the infectious disease is still a problem of the world with high mortality. Therapeutic purpose of uncomplicated malaria is to eliminate plasmodium cause infection to prevent infection severity, complications and break the chain of transmission. While the purpose therapy of severe malaria is to prevent mortality. Recommended therapy of malaria is a combination of two or more antimalarial drugs that mechanisms action kills malarial parasites in the blood and the amount of each drug works on different receptors. The use of a combination of several antimalarial drugs has become a necessity for prevention of malaria parasite strains that are resistant to certain drugs. Combination therapy include: ACTs (artemisinin combination therapies); artesunate and amodiaquin; artesunate and mefloquin; artesunate with one of the SP, lumefantrin, piperaquin, pyronaridin; antibiotic (doxyciclin, clindamycine, azithromycin), artemether-lumefantrine (AL); chloroquine and $\mathrm{SP}$; atovaquone and proguanil (Malarone)
\end{abstract}

Key words: malaria, mechanisms action, antimalarial drug

\begin{abstract}
ABSTRAK
Malaria merupakan salah satu penyakit infeksi yang sampai saat ini masih menjadi problematika dunia karena menyebabkan kematian yang tinggi. Tujuan terapi malaria tanpa komplikasi adalah mengeliminasi plasmodium penyebab infeksi secepatnya agar tidak terjadi keparahan dan komplikasi serta memutus rantai penularan. Sedangkan tujuan terapi malaria yang parah adalah mencegah kematian. Terapi malaria yang direkomendasikan adalah terapi kombinasi dua atau lebih obat antimalaria yang bekerja membunuh parasit di darah dan masing-masing obat bekerja pada reseptor yang berbeda. Penggunaan kombinasi beberapa obat antimalaria tersebut menjadi suatu keharusan untuk mencegah timbulnya galur-galur parasit malaria yang resisten terhadap obat tertentu. Terapi kombinasi tersebut antara lain : ACTs (artemisinin combination therapies); artesunat dan amodiaquin; artesunat dan mefloquin; artesunat dengan salah satu dari SP,lumefantrin, piperaquin, pyronaridin; antibiotic (doxyciclin, clindamicine, azitromisin); Artemeter-lumefantrine (AL); klorokuin dan SP; Atovaquone dan proguanil (Malarone).
\end{abstract}

Kata kunci : malaria, mekanisme, antimalaria

\section{PENDAHULUAN}

Malaria adalah penyakit menular yang disebabkan oleh parasit (protozoa) dari genus plasmodium, yang dapat ditularkan melalui gigitan nyamuk anopheles. Penyakit ini merupakan salah satu penyakit infeksi yang tersebar diseluruh dunia. Penduduk yang berisiko terkena malaria berjumlah sekitar 2,3 miliar atau $41 \%$ dari jumlah penduduk dunia. Setiap tahun sekitar 300-500 juta penduduk dunia menderita penyakit ini dan mengakibatkan 1,5-2,7 juta kematian, terutama di negara-negara benua Afrika
(WHO, 2011). Di Indonesia jumlah kabupaten/kota endemik tahun 2004 sebanyak 424 dari 579 kabupaten/kota, dengan perkiraan persentase penduduk yang beresiko penularan sebesar 42,42\%. Masalah malaria di Indonesia terutama terpusat di wilayah Indonesia bagian Timur, yaitu, Papua, Irian Jaya Barat, Maluku, Maluku Utara dan NTT (Harijanto, 2009).

Parasit yang paling sering ditemui adalah $P$. vivax dan $P$. falciparum. Daerah endemik P.falciparum adalah papua, Kalimantan, Sulawesi Utara, Lombok dan pulau-pulau di wilayah Indonesia Timur, 
sedang di pulau Jawa tersebar di Pacitan, Jepara , Kulonprogo, Tulungagung dan Malang Selatan. Plasmodium vivax penyebab malaria tertiana, secara klinis jauh lebih ringan dan jarang menimbulkan kematian dibanding $P$. falciparum. $P$ vivax paling banyak dijumpai di Asia Tenggara termasuk di Indonesia. Plasmodium malariae menyebabkan malaria, infeksi jenis ini bisa bersifat laten dan bisa bertahan sampai puluhan tahun. P. malariae banyak dijumpai di beberapa Negara Amerika Tengah, India, Afrika Barat, Papua Nugini dan Indonesia bagian Timur. Plamodium ovale menyebabkan malaria ovale yang gejala klinisnya mirip dengan malaria yang di sebabkan P.vivax. kasus $P$. ovale pernah dilaporkan di Irian Jaya dan Nusa Tenggara Timur (Harijanto, 2006).

\section{SIKLUS HIDUP MALARIA}

Plasmodium mempunyai siklus hidup yang lebih kompleks, karena selain terjadi pergantian generasi seksual dan aseksual juga mengalami pergantian hospes. Terdiri dari siklus seksual (sporogoni) yang berlangsung pada nyamuk Anopheles betina, dan siklus aseksual yang berlangsung pada manusia. Siklus hidup pada manusia terdiri dari fase exoerithrocytic di dalam parenkim sel hepar dan fase erithrocytic schizogoni (Good, 2007)

\section{Fase seksual eksogen (sporogoni) dalam tubuh nyamuk}

Nyamuk Anopheles betina mengingesti eritrosit yang mengandung mikrogametosit dan makrogametosit dari penderita. Di dalam tubuh nyamuk terjadi perkawinan antara mikrogametosit dan makrogametosit menghasilkan zigot. Perkawinan ini terjadi di dalam lambung nyamuk. Zigot berkembang menjadi ookinet, kemudian masuk ke dinding lambung nyamuk berkembang menjadi ookista, setelah ookista matang dan pecah, keluar sporozoit yang berpindah ke kelenjar saliva nyamuk dan siap untuk ditularkan ke manusia (BPPT, 2007).
2. Fase aseksual (skizon) dalam tubuh hospes perantara/manusia

a. Siklus dalam sel hepar (skizon eksoeritrositik)

Melalui gigitan nyamuk Anopheles, sporozoit masuk aliran darah selama $1 / 2-2$ jam kemudian menuju hepar untuk berkembang biak (Basuki \& Darmowandowo, 2006). Sporozoitsporozoit ini dengan cepat (beberapa menit) menginvasi sel hepar kemudian berkembang menjadi skizon eksoeritrositik. Masing-masing skizon eksoeritrositik mengandung merozoit sampai 30.000. sel hapar yang telah terinfeksi skizon eksoeritrisitik mengalami ruptur dan melepaskan merozoit dewasa ke aliran darah (Good, 2007)

\section{b. Siklus eritrosit (skizon eritrositik)}

Merozoit merozoit yang dilepaskan dari sel hepar menginvasi eritrosit, berkembang menjadi ringform, kemudian tropozoit, dan akhirnya akan menjadi skizon. Eritrosit yang mengandung skizon mengalami ruptur dan melepaskan merozoit yang siap menginvasi eritrosit yang lain. Sebagian besar merozoit masuk kembali ke eritrosit dan sebagian kecil membentuk gametosit jantan dan betina yang siap untuk dihisap nyamuk Anopheles betina dan melanjutkan siklus hidupnya di tubuh nyamuk. Siklus aseksual di eritrosit pada Plasmodium falciparum terjadi selama 48 jam (Gardiner et al , 2005)

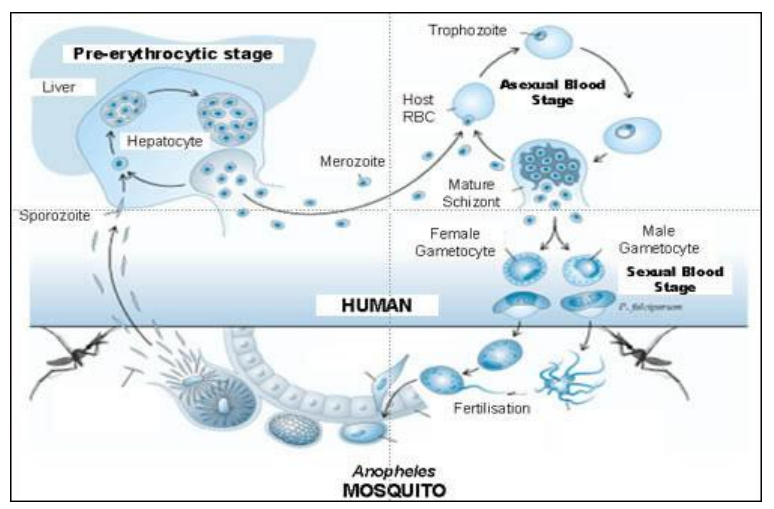

Gambar 1. Siklus hidup Plasmodium falciparum. 
Nyamuk Anopheles menggigit manusia, sporozoit masuk aliran darah. Sporozoit menginvasi hepatosit berkembang menjadi skizon eksoeritrositik. Skizon ruptur dan melepaskan banyak merozoit. Merozoit yang dilepaskan menginfeksi red blood cell (RBC), berkembang menjadi ringform, kemudian tropozoit, dan akhirnya menjadi skizon. Skizon ruptur dan melepaskan merozoit. Merozoit ada yang menginfeksi RBC kembali dan ada yang berkembang menjadi gametosit (sumber: Good, 2007)

\section{GEJALA MALARIA DAN MEKANISME PARASIT DALAM MENGINFEKSI ERITROSIT}

\section{Gejala Malaria}

Manifestasi klinis malaria tergantung pada imunitas penderita dan tingginya transmisi infeksi malaria, sedangkan berat ringannya infeksi dipengaruhi oleh jenis Plasmodium, daerah asal infeksi, umur, dugaan konstitusi genetik, keadaan kesehatan dan nutrisi, serta kemoprofilaksis dan pengobatan sebelumnya. Pada dasarnya, terdapat 3 gejala utama yang spesifik pada malaria (cardinal signs), yaitu demam paroksismal, anemia, dan splenomegali (Harijanto, 2006; Sardjono dan Fitri, 2007).

Masa inkubasi penyakit malaria, bervariasi pada masing-masing Plasmodium. Sebelum gejala klinis timbul biasanya terdapat gejala prodromal seperti lesu, sakit kepala, malaise, nyeri sendi dan tulang, mual, anoreksia, demam ringan, diare ringan, perut tak enak, dan kadangkadang terdapat rasa dingin dipunggung. Keluhan prodormal sering terjadi pada Plasmodium vivax dan Plasmodium ovale, sedangkan pada Plasmodium falciparum dan Plasmodium malariae keluhan prodormal tidak jelas bahkan gejala dapat mendadak (Tarigan, 2003; Harijanto, 2006).

Gejala yang klasik yaitu terjadinya Trias Malaria (Malaria Paroksismal) secara berurutan yaitu (Tarigan, 2003; Harijanto, 2006; Sardjono dan Fitri, 2007): a. Periode dingin

Mulai menggigil, kulit dingin dan kering, penderita sering membungkus diri dengan selimut atau sarung dan pada saat menggigil sering seluruh tubuh bergetar dan gigi gemertak, pucat sampai sianosis seperti orang kedinginan, pada anak bisa terjadi kejang. Periode ini berlangsung 15-60 menit diikuti dengan meningkatnya temperatur.

b. Periode panas

Muka penderita merah, kulit panas dan kering, nadi cepat dan panas badan tetap tinggi dapat sampai $40^{\circ} \mathrm{C}$ atau lebih. Periode ini lebih lama dapat sampai 2 jam atau lebih, seiring dengan irama siklus eritrositik kemudian dikuti keadaan berkeringat.

c. Periode berkeringat

Penderita berkeringat mulai dari temporal, diikuti seluruh tubuh, sampai basah, temperatur turun drastis, penderita merasa capek dan sering tertidur dengan nyenyak dan setelah bangun tidak ada keluhan kesuali badan lemah. Stadium ini berlangsung 2-4 jam.

Pada pasien-pasien yang tinggal didaerah endemis malaria, gejala tersebut tidak khas oleh karena penderita telah mengalami semi imun. Lebih sering dialami pada malaria klasik, yaitu penderita yang berasal dari daerah non-endemik atau yang baru pertama kali menderita malaria. Seluruh rangkaian Trias Malaria berlangsung \pm 6-10 jam. Trias malaria lebih sering terjadi pada infeksi Plasmodium vivax (Harijanto, 2006; Sardjono dan Fitri, 2007).

Beberapa keadaan klinik dalam perjalanan infeksi malaria ialah (Harijanto, 2006; Sardjono dan Fitri, 2007):

a. Serangan primer: keadaan mulai dari akhir masa inkubasi dan mulai terjadi serangan paroksismal yang dapat pendek atau panjang tergantung dari multiplikasi parasit dan keadaan immunitas penderita.

b. Periode latent: periode tanpa gejala dan tanpa parasitemia selama terjadinya 
infeksi malaria. Biasanya terjadi diantara dua keadaan paroksismal.

c. Recrudescense: berulangnya gejala klinik dan parasitemia dalam masa 8 minggu sesudah berakhirnya serangan primer yang berasal dari stadium eritrositer aseksual yang perisisten. Dapat terjadi berupa berulangnya gejala klinik sesudah periode laten dari serangan primer. Hal ini terjadi pada Plasmodium falciparum dan Plasmodium malariae, yaitu spesies yang tidak mempunyai stadium hipnozoit. Disebut juga short term relapse.

d. Recurrence: berulangnya gejala klinik atau parasitemia setelah 24 minggu berakhirnya serangan primer. Terjadi disebabkan adanya merozoit yang berasal dari stadium hipnozoit hati yang aktif kembali. Ini terjadi karena infeksi Plasmodium vivax dan Plasmodium ovale. Disebut juga long term relapse

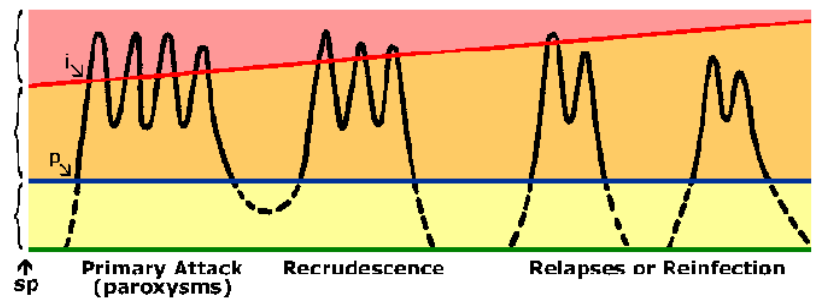

Gambar 2. Perjalanan Klinis Infeksi Malaria (Wiser,2008)

Anemia merupakan gejala yang sering dijumpai pada infeksi malaria. Derajat anemia sangat bervariasi, tergantung jenis parasit yang menginfeksi dan derajat infeksinya. Beberapa mekanisme terjadinya anemia adalah pengerusakan eritrosit oleh parasit, hambatan eritropoiesis sementara, hemolisis karena proses complement mediated immune complex, eritrofagositosis, penghambatan pengeluaran retikulosit, dan pengaruh sitokin (Harijanto, 2006; Sardjono dan Fitri, 2007).

Limpa merupakan organ yang penting dalam pertahanan tubuh terhadap infeksi malaria. Bila terjadi infeksi malaria, splenomegali akan sering dijumpai pula pada penderita malaria karena peningkatan fungsi sistem retikuloendotelial. Limpa akan teraba setelah 3 hari dari serangan infeksi akut. Limpa menjadi bengkak, nyeri, dan hiperemis. Mungkin juga dijumpai gejala kuning (jaundice) disertai pembesaran hepar dan gangguan faal hepar berupa peningkatan aktifitas enzim SGOT dan SGPT (Harijanto, 2006).

\section{Mekanisme Parasit Plasmodium falciparum dalam menginfeksi eritrosit}

a. Masuknya parasit

Masuknya parasit ke eritrosit bukan melalui uptake atau fagositosis eritrosit, karena eritrosit tidak mampu untuk fagositosis. Membran eritrosit mempunyai dua dimensi sitoskeleton submembran yang menghalangi terjadinya endositosis sehingga daya pendorong untuk pembentukan parasitophorous vacuole harus datang dari parasit. Membran eritrosit di redistribusi pada saat pembentukan junction sehingga area kontaknya bebas dari membran eritrosit. Hal ini dilakukan oleh merozoit serine protease yang memecah protein band 3 eritrosit. Protein band 3 berperan penting dalam homeostasis submembran skeleton, degradasinya dapat melokalisir sitoskeleton yang rusak kemudian parasitophorous vacuolar membrane (PVM) terbentuk di junction area. Membran ini mengalami invaginasi. Komponen rhoptry seperti membrane lamelar dan beberapa protein rhoptry terlokalisir ke dalam PVM. Ini menunjukkan bahwa rhoptry berperan dalam pembentukan PVM. Akibat pembentukan PVM, junction antara parasit dan eritrosit menjadi seperti cincin dan parasit berpindah masuk melalui annulus ini dan memperluas parasitophorous vacuole (Wiser, 2006a). PVM ini berasal dari lipid merozoit (Dluzewski et al., 1992). 


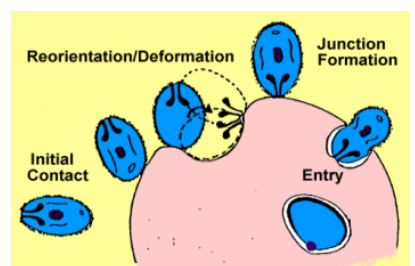

Gambar 3. Langkah invasi Merozoit (Wiser, 2006a)

\section{b. Degradasi hemoglobin oleh Plasmodium}

Hemoglobin didegradasi di dalam vakuola makanan parasit dengan menggunakan protease yang spesifik. Ketika berlangsungnya degradasi hemoglobin, heme bebas dilepaskan. Heme bebas bersifat sitotoksik , detoksifikasi heme bebas ini penting untuk berlangsungnya hidup parasit. Heme bebas pada mamalia didegradasi melalui heme oksigenase/melalui jalur biliverdin reduktase. Detoksifikasi heme pada P.falciparum melalui polimerisasi heme bebas menjadi materi kristalin soluble yang disebut hemozoin (Chang, tanpa tahun)

Struktur hemozoin mirip dengan bhematin yang merupakan dimer heme yang terbentuk melalui ikatan kovalen antara gugus asam karboksilat pada cincin protoporphyrin-IX dan atom $\mathrm{Fe}$ dari dua molekul heme. Dimer ini berinteraksi melalui ikatan hidrogen untuk membentuk kristal hemozoin. Ikatan besi dengan hemoglobin utamanya pada kondisi Fero $\left(\mathrm{Fe}^{2+}\right)$. Pelepasan heme menghasilkan besi yang dioksidasi menjadi feri $\left(\mathrm{Fe}^{3+}\right)$. Elektron dibebaskan melalui oksidasi besi ini sehingga merangsang pembentukan Reaktif Oxsigen Intermediate seperti superoksida dan hidrogen Peroksida. Superoxide Dismutase (SOD) dan katalase merupakan enzim seluler yang berfungsi untuk mencegah stres oksidatif. Aktivitas superoxide dan hidrogen peroksida ada di vakuola makanan dan diperoleh dari hospes selama ingesti sitoplasma eritrosit. Hidrogen peroksida juga dibawa ke sitoplasma parasit dimana ia didetoksifikasi oleh katalase dan gluthation peroksida. Beberapa hidrogen peroksida hasil konversi
$\mathrm{Fe}^{2+}$ menjadi $\mathrm{Fe}^{3+}$ juga digunakan untuk degradasi peroksidatif heme (Wiser, 2006b).

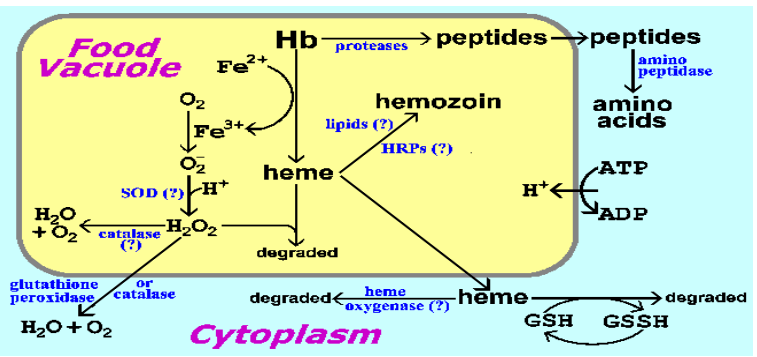

Gambar 4 Proses Degradasi hemoglobin

Hemoglobin di degradasi dengan menggunakan protease yang spesifik. Ketika berlangsungnya degradasi hemoglobin, heme bebas dilepaskan. Heme selanjutnya menjadi hemozoin. Pelepasan heme menghasilkan besi yang dioksidasi menjadi feri $\left(\mathrm{Fe}^{3+}\right)$. Elektron dibebaskan melalui oksidasi besi ini sehingga merangsang pembentukan reactive oxsygen intermediate (ROI) seperti $\mathrm{O}_{2}^{-}$dan $\mathrm{H}_{2} \mathrm{O}_{2}$. Glutation peroksidase dan katalase merupakan enzim yang merubah $\mathrm{H}_{2} \mathrm{O}_{2}$ menjadi $\mathrm{H}_{2} \mathrm{O}$ dan $\mathrm{O}_{2}$. (Wiser, 2006)

\section{c. Respon Imun Terhadap Plasmodium}

Komponen yang berperan mengatasi infeksi Plasmodium sebagai mikroba intraseluler adalah sistim imun seluler. Mekanisme tersebut dimulai dengan eritrosit yang terinfeksi Plasmodium akan di tangkap oleh antigen presenting cell (APC). Apabila eritrosit yang terinfeksi Plasmodium sudah ditangkap oleh APC, membran APC menutup, eritrosit tersebut digerakkan ke sitoplasma sel dan terbentuk fagosom. Fagosom bersatu dengan lisosom membentuk fagolisosom mengeluarkan mediator yang akan mendegradasi antigen Plasmodium menjadi peptida-peptida yang nantinya akan berasosiasi dengan molekul MHC (major histocompatibility complex) II dan depresentasikan ke sel TCD4. Saat berlangsungnya proses dan presentasi antigen tersebut, APC mengeluarkan interleukin-12 (IL-12). Ikatan antara CD40 ligand (CD40L) dan CD40 saat presentasi 
antigen memperkuat produksi interleukin12. Interleukin-12 (IL-12) mempengarui proliferasi sel $\mathrm{T}$ yang merupakan komponen seluler dan imunitas spesifik dan selanjutnya menyebabkan aktivasi dan differensiasi sel $T$. Differensiasi dan proliferasi ini tergantung dari lingkungan mikronya. Apabila sel $\mathrm{T}$ naive berada di lingkungan yang banyak IFN- $\gamma$, maka sel T naïve akan berdeferensiasi menjadi sel $\mathrm{T}$ helper 1 (Abbas dan Lichtman, 2005).

\section{OBAT MALARIA DAN MEKANISME KERJANYA}

Penggolongan obat antimalaria dapat dibedakan menurut cara kerja obat pada siklus hidup Plasmodium dan berdasarkan struktur kimia obat.

\section{Penggolongan obat malaria berdasarkan cara kerja obat pada siklus hidup Plasmodium (Martindale, 2009) :}

a. Obat anti malaria Skizontosida darah yang menyerang Plasmodia yang hidup di darah. Anti malaria jenis ini untuk pencegahan dan mengakhiri serangan klinis.

Contoh : Klorokuin, Kuinin, Kuinidin, Meflokuin, Halofantrin, Sulfonamida, Tetrasiklin, Atovakuon dan Artemisinin serta turunannya.

b. Obat anti malaria Skizontosida jaringan yang membunuh Plasmodia pada fase eksoeritrositik di hati, mencegah invasi Plasmodia dalam sel darah. Contoh : Primakuin, Proguanil, Pirimetamin.

c. Obat anti malaria Gametosida yang membunuh stadium gametosit di darah.

Contoh : Primakuin

d. Obat anti malaria Sporontosida. Obat ini tidak berpengaruh langsung pada gametosit dalam tubuh manusia tetapi mencegah sporogoni pada tubuh nyamuk.

Perbedaan mekanisme aksi obat anti-malaria ini sebagai dasar pengobatan malaria secara kombinasi. Pengobatan malaria secara kombinasi bertujuan untuk meningkatkan efikasi dan memperlambat perkembangan resistensi obat (Martindale,2009).

\section{Penggolongan obat anti malaria berdasarkan struktur kimia obat}

Penggolongan obat antimalaria berdasarkan struktur kimia disajikan pada Tabel 1.

\section{Penggolongan obat antimalaria berdasarkan tempat kerja obat anti malaria pada organel subseluler Plasmodium (Rosenthal, 2003).}

Obat antimalaria memberikan
pengaruh pada organel subseluler Plasmodium dengan mengganggu proses atau metabolisme pada organel subseluler yang berbeda. Beberapa mekanisme kerja dan target dari obat anti-malaria adalah sebagai berikut ini (Rosenthal, 2003):

a. Obat golongan 4-aminokuinolin (klorokuin, amodiakuin) dan kuinolin metanol (kuinin dan meflokuin) berkonsentrasi dalam vacoula makanan yang bersifat asam. Obat golongan ini sangat esensial dalam mengganggu proses pencernaan hemoglobin oleh parasit dengan jalan mengadakan interaksi dengan $\beta$-hematin atau menghambat pembentukan hemozoin. Target baru obat golongan ini adalah menghambat enzim plasmepsin dan enzim falcipain yang berperan dalam pemecahan globin menjadi asam amino. Hemozoin dan asam amino diperlukan untuk pertumbuhan parasit sehingga jika pembentukan dihambat maka parasit akan mati.

b. Antibiotik seperti azitromisin, doksisiklin, dan klindamisin bekerja di dalam organel plastid seperti kloroplas yang disebut apikoplas. Obat ini menghambat translasi protein sehingga progeni parasit yang diberi obat mengalami kematian. 
c. Atovakuon dan senyawa lain tertentu menghambat transport elektron dalam mitokondria dan melalui penghambatan oksidoreduktase sitokrom C. Dalam mitokondria antifolat mengganggu biosintesis folat de novo dalam sitosol.

d. Obat anti-malaria Sulfadoksin Pyrimetamin (SP) dan kombinasi baru Klorproguanil-Dapson (Lapdap) merupakan inhibitor kompetitif yang berperan dalam jalur folat.

e. Generasi obat dari Artemisin menghasilkan radikal bebas yang berfungsi untuk mengalkilasi membran parasit.

Penggolongan obat antimalaria berdasarkan tempat kerja obat anti malaria pada organel subseluler Plasmodium diilustrasikan pada gambar di bawah ini:

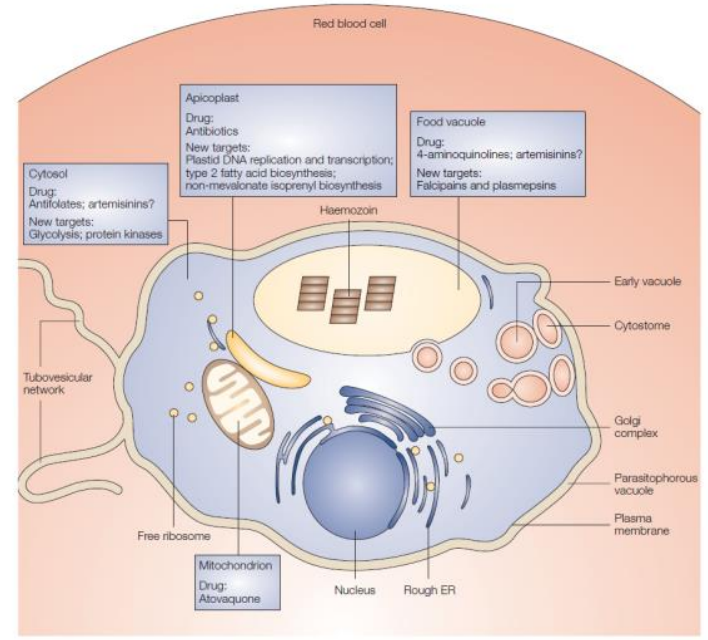

Gambar 5. Penggambaran mekanisme aksi senyawa antimalaria pada intra eritrositic

Plasmodium falciparum. Gambar ini merupakan ilustrasi dari tabel 2. (David et al, 2004)

\section{MEKANISME KERJA ARTEMISIN SEBAGAI ANTIMALARIA}

Artemisin merupakan senyawa seskuiterpen lakton yang diekstrak dari tanaman Artemisia annua. Merupakan obat baru yang berasal dari Cina (Qinghaosu) yang memberikan efektivitas yang tinggi terhadap strain yang multiresisten. Senyawa ini menunjukkan sifat skizontosida darah yang cepat, dengan waktu paruh \pm 2 jam, baik secara in-vitro maupun in-vivo, sehingga bisa digunakan untuk malaria yang berat. Selain itu artemisin mampu menurunkan transmisi malaria di daerah endemis karena artemisin bersifat gametosidal (Sukarban dan Bustomi., 1995; Tjitra, 2004; Harijanto, 2006; Felix, 2006).

Artemisin merupakan obat yang diabsorbsi dengan baik, aman, cepat diubah menjadi bentuk metabolit yang aktif, larut dalam air, aktivitasnya luas dan sangat kuat. Kelemahan dari artemisin ini adalah memerlukan waktu pengobatan lama apabila pengobatan hanya menggunakan obat artemisin (monotherapy). Penggunaan artemisin direkomendasikan dalam bentuk kombinasi dengan obat lain (ACT) agar tidak terjadi rekrudesensi. Derivat artemisin ada beberapa golongan, yaitu artesunat, artemeter, dihidroartemisin, artemisinin, arteeter, asam artelinik. Obat-obat antimalaria tersebut dapat diberikan secara oral, injeksi im/iv, maupun suppositoria (Sukarban et al., 1995; Tjitra, 2004; Harijanto, 2006).

Mekanisme kerja artemisin awalnya pada jembatan peroksida, obat artemisinin diketahui bekerja secara spesifik selama tahap eritrositik (gambar 3). Struktur jembatan peroksida artemisinin diputus oleh ion $\mathrm{Fe}^{2+}$ (ion besi II) menjadi radikal bebas yang reaktif. Radikal-radikal artemisin ini kemudian menghambat dan memodifikasi berbagai macam molekul dalam parasit yang mengakibatkan parasit tersebut mati. Sumber ion besi II intrasel adalah heme (komponen penting dalam hemoglobin), selama pertumbuhan dan penggandaannya dalam eritrosit, parasit memakan dan menghancurkan sampai $80 \%$ sel hemoglobin inang dalam vakuola makanan. Ini akan melepaskan $\mathrm{Fe}^{2+}$-hem, teroksidasi menjadi $\mathrm{Fe}^{3+}$-hematin, dan kemudian mengendap dalam vacuola makanan membentuk pigmen Kristal disebut hemozoin. Efek antimalaria dari artemisin disebabkan oleh masuknya molekul ini ke dalam vakuola makanan parasit dan kemudian berinteraksi dengan $\mathrm{Fe}^{2+}$-hem. Interaksi menghasilkan radikal 
bebas yang menghancurkan komponen vital parasit sehinnga parasit mati. (Paul et al, 2010).

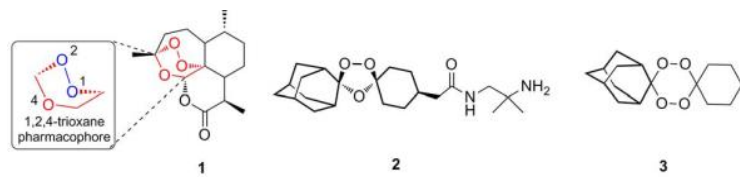

Gambar 6. Jembatan proksida yang merupakan gugus aktif (farmakofor) antimalaria senyawa artemisin (Paul et al, 2010)

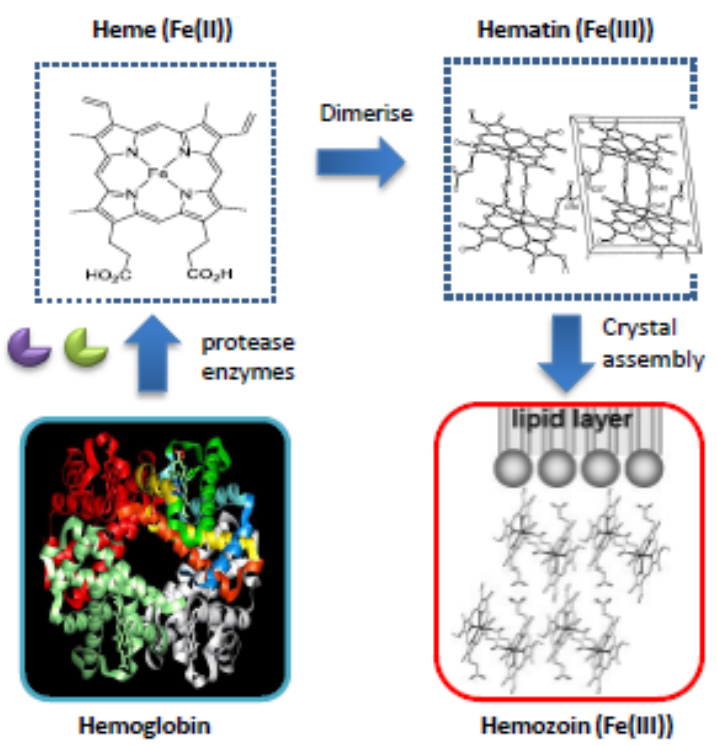

Gambar 7. Detoksifikasi hemoglobin oleh parasit ; hemoglobin oleh enzim protease akan di ubah menjadi heme $\left(\mathrm{Fe}^{2+}\right)$, kemudian heme

$\left(\mathrm{Fe}^{2+}\right)$ mengalami dimerisasi menjadi hematin $\left(\mathrm{Fe}^{3+}\right)$ yang toksik bagi parasit, selanjutnya parasit mengubah hematin menjadi hemozoin $\left(\mathrm{fe}^{3+}\right)$ yang tidak toksik bagi parasit dan sebagai sumber makanan bagi parasit (Paul et al, 2010)

Mekanisme kerja yang baru membuktikan bahwa Artemisin bekerja melalui penghambatan enzim ATPase bergantung kalsium (PfATP6) . PfATP6 mirip dengan ATPase mamalia yang terletak dalam kompartemen intrasel terbungkus membrane yang disebut retikulum endoplasma. Pada parasit kompartemen ini tersebar luas dalam sitoplasma diluar vakuola makanan parasit. Artemisin yang terbungkus di dalam gelembung membran diangkut dari eritrosit ke dalam parasit. Sekali dalam parasit Artemisin diaktifkan oleh ion besi bebas atau proses-proses yang bergantung besi lain dekat dengan PfATP6 dalam retikulum endoplasma. Radikal bebas yang dihasilkan artemisin mengikat dan menghambat PfATP6 secara ireversibel dan spesifik. Kemungkinan besar radikal bebas Artemisisnin memodifikasi berbagai sisi pada satu target tunggal dan juga dapat mengikat beberapa jenis protein-protein parasit lain. Fungsi ATPase pada sistim kompleks pompa ion $\mathrm{Na}^{+} / \mathrm{K}^{+}$adalah mengatur kadar ion di dalam sel. Kegagalan fungsi PfATP6 mengakibatkan penurunan drastis ion kalium dalam sel yang sangat mematikan parasit (Paul et al, 2010).

Artesunat adalah garam suksinil natrium artemisinin yang larut baik dalam air tetapi tidak stabil dalam larutan. Sedangkan artemeter adalah metil eter artemisin yang larut dalam lemak. Artemeter segera diserap dan mencapai kadar puncak dalam 2-3 jam. Obat ini mengalami demetilasi di hati menjadi dihidroartemisinin. Waktu paruh eliminasi artemeter sekitar 4 jam, sedangkan dihidroartemisinin sekitar 10 jam. Ikatan protein plasma beragam antar spesies, pada manusia sekitar $77 \%$ terikat pada protein (Syarif, 2007).

Pemberian artemisin harus dilakukan dengan dosis awal (loading dose) yang lebih tinggi dari dosis berikutnya. Untuk artesunat diberikan oral $600 \mathrm{mg}$ sebagai dosis awal, dilanjutkan dengan 100 mg tiap hari selama 4 hari. Untuk artemeter diberikan injeksi $160 \mathrm{mg}$ sebagi loading dose, diikuti $80 \mathrm{mg}$ per hari selama 4 hari (Sardjono dan Fitri, 2007).

\section{KESIMPULAN}

1. Malaria adalah penyakit menular yang disebabkan oleh parasit (protozoa) dari genus plasmodium, yang dapat ditularkan melalui gigitan nyamuk anopheles

2. Manifestasi klinis malaria tergantung pada imunitas penderita dan tingginya transmisi infeksi malaria, sedangkan 
berat ringannya infeksi dipengaruhi oleh jenis Plasmodium, daerah asal infeksi, umur, dugaan konstitusi genetik, keadaan kesehatan dan nutrisi, serta kemoprofilaksis dan pengobatan sebelumnya

3. Penggolongan obat antimalaria dapat dibedakan menurut cara kerja obat pada siklus hidup Plasmodium, berdasarkan struktur kimia obat, dan tempat kerja obat pada organel subseluler

Plasmodium

\section{DAFTAR PUSTAKA}

Abbas A.K. dan Lichtman A.H., 2005. Cellular and Molecular Immunology. Fifth Edition. Elseveir Saunders, Philadelphia

Basuki P.S., dan Darmowandowo W., 2006. Malaria. (online). http//www.pediatrik.com. diakses 1 juni 2009

BPPT, 2007. Siklus Parasit Malaria. Situs Kedai Iptek -BPPT

David A.F, Roshenthal, Croft L.S, Brun Reto dan Nwaka Solomon, 2004, Antimalarial Drug Discovery: Efficacy Model For Compound screening, Nature review drug Discovery Volume 3 hal.509

Dluwzewski A.R., Mitchell G.H., Fryer P.R., Griffiths S.,.Wilson R.J.M, and Gratzer W. B., 1992. Origin of the Parasitoporous Vacuole emmbran of the malaria parasite Plasmodium falciparum, in human red blod cells, journal of the Cell Science 102: 527-532

Chang H.H., Tanpa Tahun. Heme Detoxification in $\mathrm{P}$. falciparum. The Marletta lab Universityof California, Berkeley.

http://www.cchem.berkeley.edu/mm argrp/research/malaria/hrp.html. diakses Agustus, 7, 2009

Gardiner D.L., MsCarthy J.S., Trenhole K.R., 2005. Malaria in the post genomic era; Light at end of the tunnel or just another train? Posgrad Med J, 81: 5005-509

Good M., 2007. Malaria Research http://www.qimr.edu.au/research/lab s/michaelg/index.html diakses tanggal 19 Juni 2009

Harijanto P.N., 2006. Buku Ajar Ilmu Penyakit Dalam. Jakarta: PIP FKUI: 1732-1744

Harijanto P.N., Nugroho A., Gunawan A.C., 2009, Malaria dari Molekuler ke Klinis, Edisi 2, Penerbit Buku Kedokteran (EGC)

Hommel M., 2007. Artemisin : natural, sintetik, atau rekombinan. http://id.shvoong.com/medicineand-health/comparativemedicine/1858022-artemisininnatural-sintetik-atau-rekombinan/. Diakses tanggal 23 September 2009. Martindale, 2009. The Complete Drug Reference, $36^{\text {th }}$ ed. . Sweetman SC, (ed). Pharmaceutical Press, : 594595

Paul M.O, Victoria E. B. and Stephen A. W. The Molecular Mechanism of Action of Artemisinin-The Debate Continues. Review.Molecules 2010, 15, 1705-1721

Rosenthal PJ., 2003. Review Antimalarial drug discovery: old and new approaches, The Journal of Experimental Biology 206:37353744

http://jeb.biologist.org/cgi/reprint/20

6/21/3735 diakses pada 21 April 2010

Sardjono T.W., dan Fitri L.E. 2007. Malaria, Mekanisme terjadinya Penyakit dan Pedoman Penanganannya. Malang: Lab Parasit FKUB.

Sherman I.W. 1998. Malaria: Parasite biology, pathogenesis, and protection, Department of Biology, University of California :5,6,11.

Sukarban S., Bustami Z.S., 1995. Farmakologi dan Terapi Ed. 4. Jakarta: Gaya Baru: 545-559. 
Syarif A., 2007. Farmakologi dan Terapi edisi ke-4. Bagian Farmakologi. Fakultas Kedokteran Universitas Indonesia. Jakarta: Gaya Baru

Tarigan J., 2003. Kombinasi Kina Tetrasiklin pada Pengobatan Malaria Falciparum tanpa Komplikasi di Daerah Resisten Multidrug Malaria. library.usu.ac.id/download/fk/penyd alam-jerahim $p d f$. Diakses tanggal 7 September 2009. Jam 22.15.

Wiser M.F., 2006a Cellular and Molecular of Plasmodium. (online). http:www//tulane.edu/wiser/malaria diakses tanggal 15 juni 2009

Wiser M.F., 2006b. Biochemistry of Plasmodium. (online). http:www//tulane.edu/wiser/malaria diakses tanggal 15 juni 2009

World Health Organization. 2011. World Malaria Report 2011. United Nations Children's Fund, World Health Organization, Geneva, Switzerland.

http://www.rollbackmalaria.org/wm r2011/pdf/WMReport Ir.pdf 
Tabel 1. Obat Antimalaria (Martindale, 2009)

\begin{tabular}{|c|c|c|}
\hline Antimalaria & Nama obat & Aktivitas \\
\hline 4-Aminoquinolin & $\begin{array}{l}\text { Klorokuin } \\
\text { Hidroksiklorokuin } \\
\text { Amodiakuin }\end{array}$ & $\begin{array}{l}\text { Skizontosida darah yang cepat. Beberapa beraktivitas sebagai } \\
\text { gametosida. }\end{array}$ \\
\hline 8-Aminokuinolin & $\begin{array}{l}\text { Primakuin } \\
\text { Tafenokuin }\end{array}$ & $\begin{array}{l}\text { Skizontosida jaringan. Juga sebagai gametosida } \\
\text { dan beberapa beraktivitas pada tahap siklus hidup Plasmodium } \\
\text { yang lain. }\end{array}$ \\
\hline $\begin{array}{l}\text { Artemisinin } \\
\text { turunannya } \\
\text { (Seskueterpen } \\
\text { lakton) }\end{array}$ & $\begin{array}{l}\text { Artemether } \\
\text { Artesunat }\end{array}$ & Skizontosida darah \\
\hline Biguanida & $\begin{array}{l}\text { Proguanil } \\
\text { Klorproguanil }\end{array}$ & $\begin{array}{l}\text { Skizontosida jaringan dan skizontosida darah yang beraksi lambat. } \\
\text { Beberapa beraktivitas sebagai sporontosida. } \\
\text { Inhibitor dihidrofolat reduktase. }\end{array}$ \\
\hline Diaminopirimid in & Pyrimetamin & $\begin{array}{l}\text { Skizontosida jaringan dan skizontosida darah yang beraksi lambat. } \\
\text { Beberapa beraktivitas sebagai sporontosida. Inhibitor dihidrofolat } \\
\text { reduktase. } \\
\text { Biasanya digunakan dengan antimalaria lain yang inhibitor sintesis } \\
\text { folat pada tempat yang berbeda (sulfonamide atau sulfon) untuk } \\
\text { membentuk kombinasi sinergis. }\end{array}$ \\
\hline Diklorobenzilidin & Lumefantrin & Skizontosida darah \\
\hline Hidroksinaftokuinon & Atovakuon & Skizontosida darah. Biasanya dikombinasikan dengan Proguanil \\
\hline Linkos amida & Klindamisin & $\begin{array}{l}\text { Skizontosida darah. Beberapa beraktivitas sebagai skizontosida } \\
\text { jaringan. }\end{array}$ \\
\hline 4-metanol kuinolin & $\begin{array}{l}\text { Alkaloid kinkona } \\
\text { Kuinin } \\
\text { Kuinidin }\end{array}$ & $\begin{array}{l}\text { Skizontosida darah yang cepat. Beberapa beraktivitas sebagai } \\
\text { gametosida. }\end{array}$ \\
\hline & Meflokuin & Skizontosida darah \\
\hline 9-fenantren metanol & Halofantrin & Skizontosida darah \\
\hline Sulfonamida & $\begin{array}{l}\text { Sulfadoksin } \\
\text { Sulfametopirazin }\end{array}$ & $\begin{array}{l}\text { Skizontosida darah. Ihibitor sintesis dihidropteroat dan folat } \\
\text { Biasanya dikombinasikan dengan Pyrimetamin }\end{array}$ \\
\hline Sulfon & Dapson & $\begin{array}{l}\text { Skizontosida darah. Inhibitor sintesis folat. } \\
\text { Biasanya dikombinasikan dengan Pyrimetamin }\end{array}$ \\
\hline Tetrasiklin & $\begin{array}{l}\text { Doksisiklin } \\
\text { Tetrasiklin }\end{array}$ & $\begin{array}{l}\text { Skizontosida darah. Beberapa beraktivitas sebagai skizontosida } \\
\text { jaringan. }\end{array}$ \\
\hline
\end{tabular}


Tabel 2. Target dan Komponen Aktif dari Antimalaria (Rosenthal, 2003)

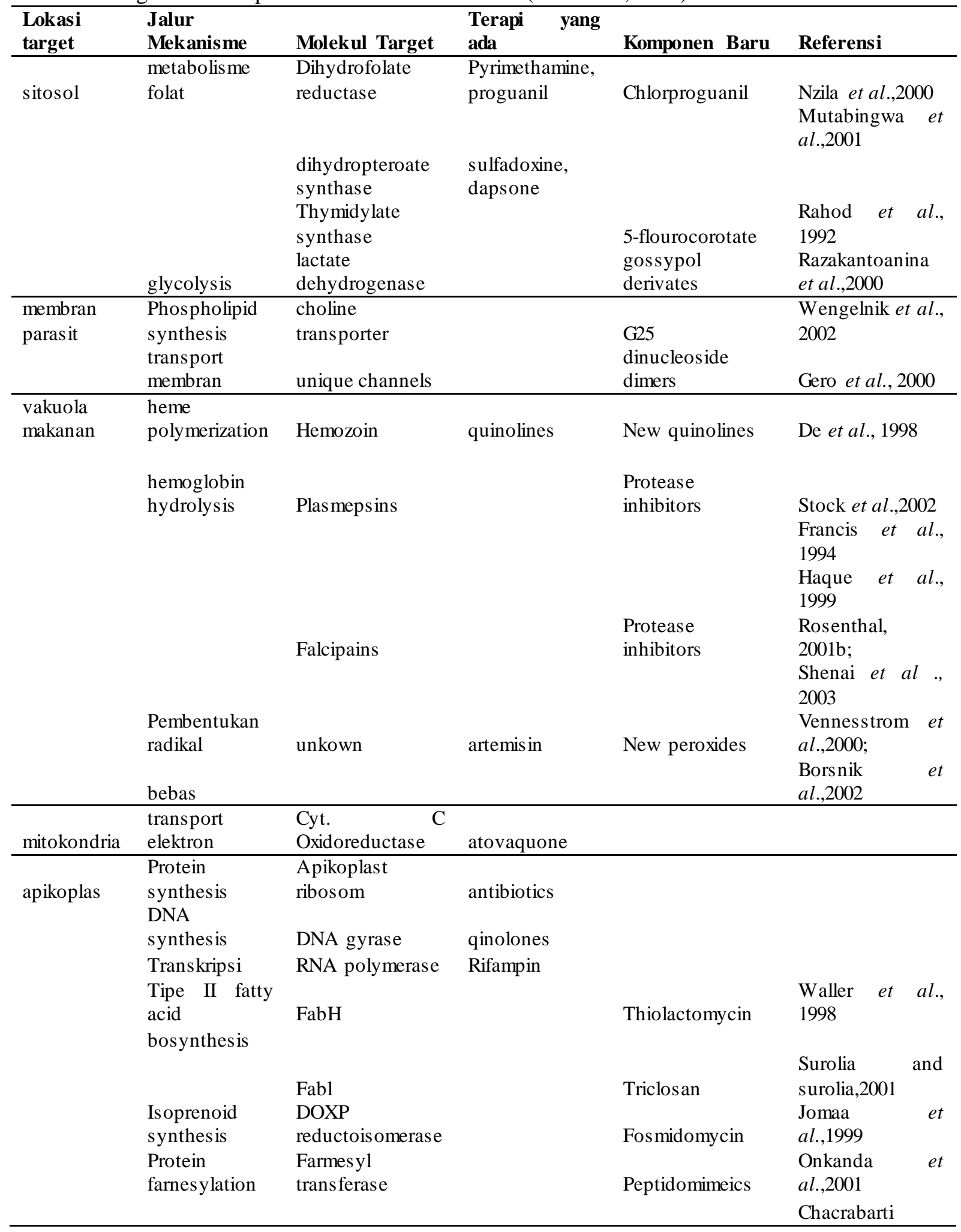

